\title{
Determination of the Performance of Local Governments with Audit Opinions as Moderation Variables in South Sumatra
}

\author{
Niken Ayuningrum ${ }^{1, *}$ Dian Ofasari ${ }^{1}$ \\ ${ }^{1}$ Accounting Study Program, Sekayu Polytechnic \\ "Corresponding author. Email: nikenayu.ningrum@yahoo.com
}

\begin{abstract}
With a case study on the Regency / City Government in South Sumatra, this study tries to establish the factors that influence local government performance using Audit Opinion as a moderating variable. The Regional Financial Independence Ratio is used to assess local government performance (RKKD). This study focuses on the districts and cities of South Sumatra, which include 14 districts and three cities. The research period is from 2016 to 2020, and the data used is secondary data. The study's findings show that regional original income and transfer funds have a positive and significant effect on local government performance, with audit opinion as a moderating variable. According to the findings of this study, the bigger the influence of PAD and Transfer Funds on the RKKD, the higher the audit opinion score. This is due to the fact that the BPK has conducted an audit in the area. This is due to the existence of an audit by the BPK in the form of an audit opinion so that transparency and accountability of state finances can be realized. In addition, the audit opinion is also a form of assessment of whether the government has worked economically, effectively and efficiently.
\end{abstract}

Keywords: Local Revenue (PAD), Transfer Revenue, Local Government Performance and Audit Opinion.

\section{INTRODUCTION}

In support of regional autonomy, the federal government delegated authority to the local government to manage its own issues. The goal of developing regional autonomy is to lessen local governments' reliance on the federal government, allowing for regional independence to be realized [1]. So regional autonomy can provide freedom for local governments in managing their regional finances and explore the potential that the region has in order to achieve economic growth through improving regional performance and public services.

The achievement of economic growth and community welfare also comes from the procedures for managing regional finances effectively and efficiently. Regional financial management that is effective and efficient will have an impact on the region's performance, with one indicator being an increase in Regional Native Income (PAD). Regional financing comes from a variety of sources, including Regional Original Income (PAD) and Transfer Revenue, particularly balancing funds such as the Special
Allocation Fund (DAK), General Allocation Fund (DAU), and Revenue Sharing Fund (DBH) [5]. The government's policy is intended so that there are no fiscal gaps and differences in capabilities in each region. But the use of DAU is considered higher when compared to a number of other uses of Balance Funds, in the hope that the use of DAU can be managed appropriately so as to encourage economic development in the region.

The local government in South Simatera is also trying to increase independence in managing regional finances. Here is data on the development of PAD and Transfer Revenue, especially DAU in South Sumatra in rupiah for Regencies and Cities in 2016 to 2020 in table 1 as follows : 
Table 1. PAD Data and Transfer Funds 2016 to 2020 (In Billions)

\begin{tabular}{|c|c|c|}
\hline Tahun & PAD & Transfer Funds \\
\hline 2016 & $219.269,84$ & $1.632 .451,80$ \\
\hline 2017 & $311.159,39$ & $1.845 .901,01$ \\
\hline 2018 & $273.850,10$ & $2.094 .763,31$ \\
\hline 2019 & $315.118,10$ & $2.409 .297,63$ \\
\hline 2020 & $304.123,86$ & $2.367066,46$ \\
\hline
\end{tabular}

Source: BPK Perwakilan South Sumatra 2021

According to table 1 above, PAD will fluctuate from 2016 to 2020, however Transfer Funds will increase every year. The local administration in South Sumatra is still reliant on balance finances in general.

Then there was the scenario where, after receiving a substantial amount of DAU transfer aid, the local government wanted the amount of Transfer Funds received in the following quarter to remain the same or even increase. Ndadari and Adi's research [6] backs this up which states that local governments behave asymmetrically by manipulating data on the amount of government spending to be as high as Do not strive to boost PAD in the hopes of receiving support from the central government in the form of transfers.

Whereas it should be with the policy of funds transfer assistance, local governments can allocate the source of funds received for development in productive sectors so as to increase regional investment which then has an impact on increasing PAD receipts. Regional financial management must be carried out with transparency and accountability, and financial statements made by local governments will be audited by the Audit Board (BPK) and given an opinion. This study included audit opinion as a moderation variable to find out the audit opinion statement by the Audit Board (BPK) regarding the level of fairness of information and financial comparison or government performance in each region.

Further audit opinions obtained by BPK inspection are meant to ensure state financial openness and accountability, as well as to learn about government agencies' attempts to improve people's welfare [2]..

Researchers are interested in doing study on the determination of local government performance using Audit Opinion as a moderation variable using case studies at the Regency / City Government in South Sumatra, based on the above context.

\section{REVIEW OF THE LITERATURE}

\subsection{Local Native Income (PAD)}

The Original Regional Money, hereinafter referred to as PAD, is the income earned by the Region and collected under the Regional Regulation in compliance with the laws and regulations, according to Law No. 33 of 2004 article 1 paragraph 18. As a result, the region's initial revenue is the outcome of the local government's efforts in managing the region's source of wealth or potential, which will then be used as financing, either for regional spending or to fund local governments' obligations and responsibilities. As a result, the quantity of PAD generated by the local government will influence the region's financial performance.

\subsection{Transfer Funds}

The Balance Fund is a cover drawn from state budget revenues granted to the Region to fund regional requirements in the context of decentralization implementation, according to Law No. 33 of 2004. The goal of the Balance Fund is to close the budget deficit between the federal government and local governments. A system of financial division that is fair, proportionate, democratic, transparent, and efficient between the Central Government and Local Government is known as financial balance. In the context of decentralizing financing, taking into account the region's potential, conditions, and needs, as well as the amount of cash available for implementation (Law No. 33/2004).

The definition of transfer funds, according to PP Number 55 on Transfer Funds from 2005, is "funds sourced from state budget revenues transferred to regions to fund regional requirements in the context of decentralization implementation." In general, the central government transfers funds to the local government for the following reasons:

1. To achieve a financial balance between the central and local governments.

2. An endeavor to increase the efficiency of government spending by delegating some responsibility in the field of state financial management, with the goal of ensuring that the gains accrue to the people in the affected area. Revenue Sharing Funds, General Allocation Funds, and Special Allocation Funds are the three types of transfer funds. 


\subsection{Audit Opinion of the Audit Board of The Audit Board (BPK)}

According to Agoes [7], auditing is a critical and methodical review of financial statements generated by management, as well as bookkeeping records and supporting data, by independent parties with the goal of being able to give an opinion on the financial statements' fairness. As mentioned in the Semester Examination Outcomes, the results of the examination or auditing done by the BPK are in the form of opinions, findings, conclusions, or recommendations (IHPS).

The conclusions of the Audit Board's (BPK) financial examinations are expressed as opinion comments about the level of fairness of information given in the government's financial accounts. In other words, the BPK opinion is a professional statement or bpk opinion as a conclusion coming from a study of the level of fairness of financial information given in the financial statements.

\subsection{Financial Performance of Local Goverments}

Financial performance refers to the results or accomplishments made by the company's management in properly managing the company's assets through time. Financial performance is required by the company in order to determine and evaluate the company's success rate based on financial operations [8]. Furthermore, a financial and non-financial indicator of a job performed or the results obtained from an activity, a process, or an organizational unit is classified as measurement or measurement of performance. Higher assessment becomes the direction that must be followed when it comes to performance measuring.

Indicators to measure local governments' efforts to improve performance can be measured in a variety of ways, one of which is through the use of the Regional Financial Performance Ratio. PAD Effectiveness Ratio, Regional Financial Efficiency Ratio, Harmony Ratio, Growth Ratio, and Regional Financial Independence Ratio are some of the ratios that can be employed. The researchers' financial performance was measured using the Regional Financial Independence Ratio in this study (RKKD).

The Regional Financial Independence Ratio (RKKD) measures a region's ability to fund government activities, development, and services to communities that have contributed to the region's financial needs through taxes and levies.

The magnitude of Regional Original Income compared to Regional Income generated from other sources (Transfer Income) includes, but is not limited to, tax revenue sharing, non-tax revenue share of natural resources, general allocation fund and special allocation, emergency fund and loan [9]. The Independence Ratio is calculated using the following formula:

$$
\mathrm{RKKD}=\frac{\mathrm{PAD}}{\text { Transfer Revenue }} \times 100 \%
$$

Financial establishment consists of:

Very Low: $0 \%-25 \%$

Low : $25 \%-50 \%$

Moderate: $50 \%-75 \%$

Height: $75 \%-100 \%$

\subsection{Hypothesis}

The hypotheses in this study are:

H1: PAD has an impact on local government performance.

H2: Local Government Performance is Affected by Transfer Funds.

H3: Local governments' performance is influenced by BPK opinion.

H4: the interaction of PAD and BPK opinions affects local government performance,

H5: Interaction of Transfer Funds and BPK Opinions affects Local Government Performance

H6: PAD and Treansfer Funds affect Local Government Performance with Audit Opinions as Moderation Variables.

\section{RESEARCH METHODS}

\subsection{Population and Sample}

In this study, the population taken was the Regency / City Government in South Sumatra, which is as many as 14 districts and 3 cities. For the selection of sample techniques selected in this study is a saturated sample technique that is all populations are sampled.

The Financial Statements of the Regency / City Government in South Sumatra are used in this study, which is a sort of quantitative research in which researchers process secondary data as a source of data for research.

In this study data collection techniques are carried out through documentation or secondary data and will be analyzed with the help of SPSS programs. This study used 5 years of research from 2016 to 2020 . 


\subsection{Data Testing}

In this study the data tests conducted are:

\subsubsection{Classic Assumption Test}

In this test to ensure that the data is normal and viable or BLUE. Classic assumption tests include:

1) Normalistas Test

2) Multicollinearity Test

3) Autocoleration Test.

\subsubsection{Descriptive Statistics}

Descriptive statistics are statistics used to describe data that has been collected.

\subsubsection{Multiple Regression Test}

Multiple regression analysis, dubbed linear since each estimate of the value is predicted to increase or decrease in a straight line, was used to measure variable effect incorporating more than one free variable (X1, $\mathrm{X} 2, \mathrm{X} 3)$.

\subsubsection{Determination Coefficient Test ( $R 2)$}

The coefficient of determination (R2) fundamentally assesses the model's capacity to explain variations in dependent variables, according to (Ghozali, 2012 in Marlisa, 2016) [10]. Between zero and one is the coefficient of determination. The ability of independent variables to explain the fluctuation of dependent variables is severely constrained when the $\mathrm{R} 2$ value is low.

\subsubsection{Hypothesis Test}

The $\mathrm{t}$ (partial) statistical test is used to see how each free variable affects the constrained variable independently. The statistical test $\mathrm{F}$ determines whether all of the model's dependent variables have a combined effect on independent variables.

\section{RESULTS OF RESEARCH AND DISCUSSION}

\subsection{Research Results}

\subsubsection{Sample Data}

The number of sample districts / cities used in this study is as many as 17 districts / cities in the South Sumatra region data from 2016 to 2020. Table 2 shows the samples that were taken based on the data's completeness.:
Table 2. Number of Regencies/Cities in 2020

\begin{tabular}{|c|l|c|}
\hline No. & \multicolumn{1}{|c|}{ Description } & amount \\
\hline 1. & Number of Cities & 3 \\
\hline 2. & Number of Districts & 14 \\
\hline & amount & 17 \\
\hline
\end{tabular}

\subsubsection{Multiple Linear Regression Analysis}

Prior to using multiple regression analysis to assess hypotheses, a series of classical assumption tests (normality, autocorrelational multicollinearity and heteroskedastisity) were conducted on the research data. The results of classical assumption testing show that research data deserves to be tested with a multivariate approach using multiple regressions.

To examine the impact of factors that affect local government performance using audit views as moderation variables, the Moderated Regression Analysis (MRA) model is used with the following equations.

Equation (1)

$$
\mathrm{Y}=\mathrm{a}+\mathrm{b} 1 \mathrm{X} 1+\mathrm{b} 2 \mathrm{X} 2+\mathrm{b} 3 \mathrm{X} 3+\mathrm{e}
$$

Equation (2) with moderation.

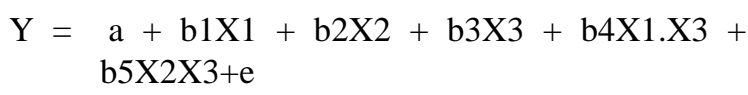

Information:

Y: Financial performance (Variable Bound)

$\mathrm{X}(1,2,3)$ : independent variable

$\mathrm{X} 1$ : Local Original Income

X2: Transfer Revenue

X3: Audit Opinion

a: constant value

b: regression coefficient value

Hypothesis testing using multiple regressions appears in table 3 below: $\mathrm{s}$ 
Table 3. Multiple Regression Analisis Coefficient ${ }^{\mathrm{a}}$

\begin{tabular}{|l|r|r|r|r|r|}
\hline Model & \multicolumn{2}{|l|}{$\begin{array}{l}\text { Unstandardized } \\
\text { Coefficients }\end{array}$} & $\begin{array}{r}\text { Standardized } \\
\text { Coefficients }\end{array}$ & \multirow{2}{*}{ Sig. } \\
\cline { 2 - 5 } & \multicolumn{1}{|c|}{ B } & Std. Error & Beta & & \\
\hline (Constant) & $-12,196$ & 89,345 & &,- 137 &, 892 \\
PAD & 1,591 &, 214 &, 641 & 7,419 &, 000 \\
Transfer &,- 561 &, 065 &,- 751 & $-8,623$ &, 000 \\
Opini & 20,629 & 22,737 &, 070 &, 907 &, 367 \\
\hline
\end{tabular}

a. Dependent Variable: KRRD

$\mathrm{R}^{2} \quad: 0,526$

Adjusted $\mathrm{R}^{2} \quad: 0,508$

Sign F $\quad: 0.000$

Source: Data processed 2021

An alternate hypothesis is accepted based on table 7, which shows that the p-value of 0.000 is less than 0.05 . This suggests that regression models can be used to forecast local government performance as measured by RKKD numbers, or that PAD variables, Transfer Funds, and Audit Opinions have an impact on their dependent variables, namely RKKD numbers.

With an adjusted R2 of $0.508, \mathrm{PAD}, \mathrm{DAU}$, and Audit Opinion variables can explain 50.8 percent of RKKD changes. Other variables outside the model can affect the remaining 49.2 percent.

The resulting regression equation (1) is as the following:

$$
\begin{aligned}
& \mathrm{Y}=-12,196+1,591 \text { PAD }- \text { 0,561 Transfer }+20,629 \\
& \quad \text { Opini }+\mathrm{e}
\end{aligned}
$$

And for the Equation (2)

$$
\begin{aligned}
& \mathrm{Y}=\mathrm{a}+\mathrm{b} 1 \mathrm{X} 1+\mathrm{b} 2 \mathrm{X} 2+\mathrm{b} 3 \mathrm{X} 3+\mathrm{b} 4 \mathrm{X} 1 . \mathrm{X} 3+ \\
& \mathrm{b} 5 \mathrm{X} 2 \mathrm{X} 3+\mathrm{e}
\end{aligned}
$$

Table 4. Multiple Regression Analaisis Coefficients ${ }^{\mathrm{a}}$

\begin{tabular}{|l|r|r|r|r|r|}
\hline Model & \multicolumn{2}{|l|}{$\begin{array}{l}\text { Unstandardized } \\
\text { Coefficients }\end{array}$} & $\begin{array}{l}\text { Standardiz } \\
\text { ed } \\
\text { Coefficien } \\
\text { ts }\end{array}$ & \multicolumn{1}{|c|}{$\mathrm{t}$} & Sig. \\
\cline { 2 - 5 } & \multicolumn{1}{|l|}{$\mathrm{B}$} & Std. Error & \multicolumn{1}{|c|}{ Beta } & & \\
\hline (Constant) & 25,903 & 173,380 & &, 149 &, 882 \\
PAD & 1,588 &, 216 &, 639 & 7,352 &, 000 \\
1Transfer & $-1,201$ & 2,491 & $-1,607$ &,- 482 &, 631 \\
Opini & 11,060 & 43,700 &, 038 &, 253 &, 801 \\
$\begin{array}{l}\text { Transfer } \\
\text { xOpini }\end{array}$ &, 160 &, 624 &, 863 &, 257 &, 798 \\
$\begin{array}{l}\text { PADxO } \\
\text { pini }\end{array}$ &, 186 &, 065 &, 300 & $, 2,869$ & 0,005 \\
\hline
\end{tabular}

a. Dependent Variable: RKKD

$\begin{array}{ll}\text { R2 } & : 0,526 \\ \text { Adjusted R2 } & : 0,503 \\ \text { Sign F } & : 0.000 \\ \text { Source: Data processed } 2021\end{array}$

Table 4 reveals that the p-value of 0.000 for the moderation variable PAD x Opinion is less than 0.05 , indicating that an alternate hypothesis is acceptable. The Transfer Fund x Opinion of 0.798, on the other hand, is less than 0.05 . This means that regression models can be used to predict local government performance as measured by RKKD numbers, or that moderation variables influence their dependent variables, namely RKKD, but for modern variables, Adjusted R2 is 0.503, implying that moderation variables can explain 50.3 percent of RKKD changes. Other variables outside the model can have an impact on the remaining $49.7 \%$. When compared to Adjusted R2 in the first equation model, Adjusted R2 in the second equation model fell by 0.005 percent.

The resulting regression equation (2) is as follows:

$$
\begin{gathered}
\mathrm{Y}=\mathbf{2 5 , 9 0 3}+1.588 \text { PAD }- \text { 1,201 Transfer }+ \text { 11,060 } \\
\text { Opini }+0,186 \text { (PADxOpini) }+ \text { 0,160 } \\
\text { (TransferxOpini) }+\mathrm{e}
\end{gathered}
$$

\subsection{Discussion}

\subsubsection{PAD affects local government performance}

The first hypothesis resulted in a significant level value of the $t$ test for a PAD variable of 0.000 less than $=0.05$ and a regression coefficient value of 1.591 for the first hypothesis (H1). This can be taken as a positive and significant influence of Regional Original Income on the Regional Financial Independence Ratio statistic, indicating that $\mathrm{H} 1$ is acceptable. The study's findings revealed that the higher a region's PAD, the higher its RKKD value. This indicates that the higher the pad, the better the performance of local governments in meeting the demands of local communities, such as in education, health, and other development areas, in order to improve the quality of human existence.

The findings of this study are consistent with those of Rustiyaningsih and Immanuela[11], who found that PAD had an impact on the performance of local governments in 275 Indonesian districts and towns..

\subsubsection{Transfer Funds affect the Performance of Local Governments}

The second hypothesis result $(\mathrm{H} 2)$ has a regression coefficient value of -0.105 and a test significance level value $\mathrm{t}$ for the Transfer Fund variable of 0.000 less than $=0.05$. As a result of these findings, $\mathrm{H} 2$ was rejected since the Transfer Fund had a negative and significant influence on the RKKD statistics. The findings of this study reveal that the greater the amount of Transfer Fund received from the federal government, the lower 
the number of Regional Financial Independence Ratios in the area. This indicates that transferring funding from the federal government to local governments will not improve their performance.

The prevalence of transfers from the central government causes local governments to rely more on transfer funds, lowering their performance, as indicated by the existence of transfer funds, particularly DAU, which is increasing in regencies / cities in south Sumatra from 2016 to 2020 . This study supports the findings of Lugastoro, Ananda, and Budi [4], who found that DAU has a negative impact on the Regional Financial Independence Ratio. According to the explanation, there is an increase in DAU transfers but a decline in RKKD since the basic allocation component continues to dominate the overall DAU received by the region. The basic allocation in question is the portion of the budget allocated for regional personnel expenditures.

Whereas it should be with the policy of funds transfer assistance, local governments can allocate the source of funds received for development in productive sectors.

\subsubsection{BPK opinions affect the performance of local governments}

The third hypothesis (H3) had a significant level value of 0.367 larger than $=0.05$ in the $t$ test for the Audit Opinion variable and a coefficient value of 20.629. As a result, $\mathrm{H} 3 \mathrm{a}$ is allowed because the audit opinion has a favorable but negligible influence on the regional financial independence ratio data. The findings revealed that the greater an area's audit opinion score, the higher the RKKD figures will be. As a result, the audit opinion is stated to have an impact on local government performance. The higher the rating of the Local Government Financial Report, the better the performance of the local government.

The findings of this investigation are consistent with previous research : Kusumawardani (2015) and (Masdiantini and Erawati (2016) which stated that audit opinions have a positive and significant effect on the performance of local government implementation

\subsubsection{The interaction of PAD and BPK Opinion affects the Performance of Local Governments}

The fourth hypothesis result for the moderation variable $(\mathrm{H} 4)$ obtained the result of the significance level value of the test $t$ for the audit opinion moderation variable affecting the relationship between PAD H4 is acceptable since RKKD is 0.005 less than $=0.05$ and the coefficient value is 0.031 . This demonstrates that the audit opinion has a favorable and considerable impact on RKKD pad relationships. The results of this study mean that the higher the audit opinion score, the influence of PAD on RKKD is increasing. This situation shows that with the audit opinion can encourage the performance of local governments to increase by the increase in PAD which is then allocated to the productive sectors of RKKD, including education, health, and other human development sectors.

This is because the examination by the BPK in the form of audit opinions is intended so that transparency and accountability of the country's finances can be realized. In addition, audit opinion is also a form of assessment of whether the government has worked economically, effectively and efficiently

\subsubsection{Interaction of Transfer Funds and BPK Opinions affects the Performance of Local Governments}

The fifth hypothesis result for the moderation variable (H5) obtained the results of the significance level value of the test $t$ for the audit opinion moderation variable affecting the relationship between DAU and RKKD by 0.798 greater than $\alpha=0.05$ and coefficient value of -0.160 . This suggests that audit opinions are influential but small, and that they can regulate the DAU-RKKD relationship in a negative direction, allowing $\mathrm{H} 5$ to be approved. According to the findings of this study, adding one audit opinion score increases the influence of transfer funds on RKKD by 0.160 .

This situation shows that with the audit opinion encourages local governments to further strive to improve $\mathrm{PAD}$ as financing of its regional needs By allocating cash to productive sectors in order to improve the quality of human usage, aided by the utilization of central government transfer funds. So that, based on the audit view, the utilization of transfer money can be used to sway local government decisions to provide more resources to productive sectors.

\subsubsection{PAD and Treansfer Funds affect local government performance with audit opinions as moderation variables}

The sixth hypothesis result for pad variables and Treansfer funds affects the performance of local governments with audit opinions as moderation variables (H6) obtained the results of the value of the significance level of the test $\mathrm{F}$ for variable moderation of audit opinion affect the relationship between PAD and Transfer Fund with RKKD of 0.000 smaller than $\alpha$ $=0.05$. H6 has been accepted. This demonstrates that the audit opinion has a favorable and considerable impact on the RKKD link between PAD and Transfer Funds. The results of this study mean that the higher the audit opinion score, the influence of PAD and Transfer Funds on RKKD is increasing. This is because the examination by the BPK in the form of audit opinions is intended so that transparency and accountability of the country's finances can be realized. 
In addition, audit opinion is also a form of assessment of whether the government has worked economically, effectively and efficiently

\section{CONCLUSIONS, LIMITATIONS AND SUGGESTIONS}

\subsection{Conclusion}

The following are the findings of this study, based on data analysis and discussion:

1. Regional Original Income has a positive and significant impact on the performance of district / city local governments in the South Sumatra region from 2016 to 2020.

2. In the South Sumatra region, transfer funds have a negative and significant impact on district/city local government performance from 2016 to 2020 .

3. In the South Sumatra region from 2016 to 2020, the Audit Opinion has a positive but modest effect on the performance of district / city local governments.

4. Positive interaction between local native income and audit opinion

5. and important to the performance of the regional administration of districts / cities in the South Sumatra area in the years 2016-2020.

6. In the South Sumatra region, the interaction between Transfer Funds and Audit Opinions has a positive but minor influence on district/city government performance from 2016 to 2020.

7. With audit opinions as moderating variables, PAD and Transfer Funds have a favorable and significant effect on local government performance...

\subsection{Limitations}

Limitations in this study are:

1. Data used only up to year 5 and free variables namely PAD, bpk transfer funds and opinions, and moderation variables used in this study that is CPC opinion can only explain a small portion of bound variables, the rest can be explained by other variables outside the model.

2. Therefore, further research is suggested to be able to use other more relevant variables such as as measurements of local government performance such as regional financial independence ratios.

3. The variable of moderation of audit results used in this study only uses audit opinions because the completeness of other audit results data is not adequate, so that for further research it is recommended to use other audit results such as audit findings, and audit conclusions.

\subsection{Suggestion}

Advice that can be recommended to local governments, namely

1. Local Government should be able to utilize potential resources and regional economic sectors so that Regional Original Income (PAD) can increase so that the region can be more independent in carrying out its own regional operational and development activities.

2. As for the receipt of Transfer Funds should be utilized as wisely as possible so that the inequality that occurs between regions can be resolved immediately and service activities to the public can be implemented properly.

3. Local governments in south Sumatra can maintain and maintain audit opinions on financial statements because almost one hundred percent have a fair opinion without exception

\section{REFERENCES}

[1] Hasthoro, Handoko A, and Sunardi. 2016. "Public Governance and Financial Performance of Local Governments in Indonesia." Journal of Economics and Business Volume XIX, No. 1 53-68.

[2] Financial Examiner's Office. 31, 2015. www.bpk.go.id. Central Bureau of Statistics. 2015. Retrieved 2016. www.bps.go.id. Central Bureau of Statistics. July 8, 2017. Accessed July 8, 2017. ww.bps.go.id. Village Accounting. Jakarta: Salemba Four.

[3] Ghozali, I. (2013). Multivariate Analysis Application with IBM SPSS 21Update PLS Regression Program. Semarang: Diponegoro University Issuing Board.

[4] Budi, Aris Setia. 2017. "The Influence of Regional Original Income, Regional Balance and Expenditure Funds to Regional Financial Independence Ratio in Regency / City Government in Central Java in 2012-2014

[5] Mulya, R. dan Bustaman. 2016. Pengaruh Flypaper Effect pada Dana Alokasi Umum dan Pendapatan Asli Daerah Terhadap Pertumbuhan Ekonomi di Kota Banda Aceh. Jurnal Ilmiah Mahasiswa Ekonomi Akuntansi 1(2): 190- 198

[6] P, H, Adi, and L, W, Ndadari, 2008, Perilaku Asimetris Pemerintah Daerah Terhadap Transfer Pemerintah Pusat. The 2nd National Conference UKWMS Surabaya, 6 September 2008.

[7] Agoes,Sukrisno.2013.Auditing: (Pemeriksaan Akuntan) oleh Kantor Akuntan Publik Jilid I. 
Jakarta: Lembaga Penerbit Fakultas Ekonomi Universitas Indonesia

[8] Rudianto. 2013. Akuntansi Manajemen Informasi untuk Pengambilan Keputusan Strategis. Jakarta: Erlangga

[9] Abdul Halim. 2007. Akuntansi Sektor Publik: Akuntansi Keuangan Daerah. Jakarta : Salemba Empat
[10] Ghozali, Imam. 2012. Aplikasi Analisis Multivariate dengan Program IBM SPSS. Yogyakarta: Universitas Diponegoro

[11] Rustiyaningsih, Sri and Immanuela, Intan (2014) Faktor-faktor yang mempengaruhi kinerja Pemerintah Daerah. Widya Warta: Jurnal Ilmiah Universitas Katolik Widya Mandala Madiun, 38 (02). pp. 190-202. ISSN 0854-1981 